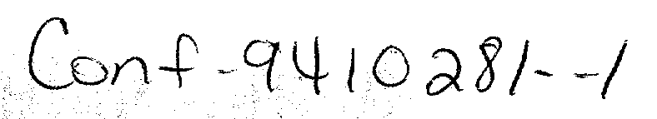

BNI -61277

\title{
SYNTHESIS, TISSUE UPTAKE, AND TOXICITY OF A NICKEL
} TETRACARBORANYLPHENYLPORPHYRIN

Michiko Miura, ${ }^{1}$ Peggy L. Micca, ${ }^{1}$ Jason A. Donaldson, ${ }^{1}$ John C. Heinrichs, ${ }^{1}$ John A. Shelnutt $^{2}$, Gerald C. Finkel, ${ }^{3}$ and Daniel N. Slatkin 1

1Medical Department, Brookhaven National Laboratory, Upton, New York 11973 U.S.A.

2Fuel Science Department, Sandia National Laboratory, Albuquerque, New Mexico 87185 U.S.A.

3Thomas Jefferson University, Philadelphia, Pennsylvannia 19107 U.S.A.

1. INTRODUCTION

Porphyrins have been used for boron neutron capture therapy [BNCT] and photodynamic therapy [PDT] of experimental rodent tumors. PDT requires much less porphyrin than BNCT, typically $5 \mu \mathrm{g}$ as compared to $>200 \mu \mathrm{g}$ per gram body weight [gbw]. Toxicity is a major consideration in the use of boronated drugs for BNCT. At $265 \mu \mathrm{g} / \mathrm{gbw}$, a boronated porphyrin, VCDP [1] (Figure 1) delivered $40 \mu \mathrm{g} \mathrm{B/g}$ to tumor tissue 4 days after the last of 12 intraperitoneal [ip] injections. 1 There was transient hematologic and hepatic toxicity. If the VCDP dose rate was kept low ( $22 \mu \mathrm{g} / \mathrm{gbw}$ per ip injection; 12 injections over 4 days), lethality was under $10 \%$. A tetraphenylporphyrin [2] containing four meta-nido-carborane cages was synthesized 2 and when tested in mice found to be much more toxic than VCDP. Figure 1. Structure of VCDP 1 and porphyrin 2.

A lipophilic nonplanar nickel porphyrin NiTCP [5] structurally similar to 2, was synthesized with eight methyl acetate and four carboranylphenyl groups. NiTCP was emulsified with Cremophor EL (Sigma Chemical Co., St. Louis, MO) in saline for testing in mice ${ }^{3}$ Of three groups of mice, one was given NiTCP, another VCDP and the third, only solvent. Clinical chemistry analyses and tissue boron concentrations were measured in these groups.

\section{METHODS}

2.1 Chemistry.

VCDP was synthesized as described. 2 NiTCP was synthesized using Lindsey's cyclization method4; precursers pyrrole $3^{5}(79 \mathrm{mg}, 0.37 \mathrm{mmol})$ and benzaldehyde $4^{2}$ (91 $\mathrm{mg}, 0.33 \mathrm{mmol}$ ) were dissolved in $\mathrm{CH}_{2} \mathrm{Cl}_{2}\left(20 \mathrm{~mL}\right.$ ) and degassed with $\mathrm{N}_{2}$ for 20 minutes (Figure 2). $\mathrm{BF}_{3} \cdot \mathrm{Et}_{2} \mathrm{O}(2.5 \mathrm{M}, 15 \mu \mathrm{l})$ was added and the reaction was allowed to stir at $25^{\circ} \mathrm{C}$ under $\mathrm{N}_{2}$ for 1.5 hours. The reaction was monitored using absorption spectroscopy by oxidizing each aliquot containing porphyrinogen with dichlorodicyanobenzoquinone (DDQ). After the characteristic porphyrin dication spectrum was observed, the reaction was oxidized with DDQ (73 $\mathrm{mg}, 0.32 \mathrm{mmol}$ ). UV-vis

$\left(\mathrm{CH}_{2} \mathrm{Cl}_{2}\right) \lambda_{\max } \mathrm{nm}: 475,704$.

Figure 2. Synthetic scheme for NiTCP 5.

The crude reaction mixture in $\mathrm{CHCl}_{3}$ was treated with $\mathrm{Ni}(\mathrm{OAc})_{2} / \mathrm{MeOH}$ at reflux until the optical spectrum showed only metalloporphyrin ( $\approx 2$ hours). The nickel porphyrin was purified by preparative TLC ( $2 \times 2 \mathrm{~mm} \mathrm{SiO} 2, \mathrm{CH}_{2} \mathrm{Cl}_{2}$ eluent). Yield from pyrrole: $44 \mathrm{mg}$ (0.023 mmol), 28\%. NMR (CDCl3): 7.8-7.2 (m, 16H, ArH); 4.59 (s, 8H, $\left.\mathrm{CH}_{2} \mathrm{~B}_{10} \mathrm{H}_{10}\right) ; 4.16\left(\mathrm{~s}, 4 \mathrm{H}, \mathrm{B}_{10} \mathrm{H}_{10} \mathrm{CH}\right) ; 3.36\left(\mathrm{~s}, 24 \mathrm{H}, \mathrm{OCH}_{3}\right) ; 3.26(\mathrm{~s}, 16 \mathrm{H}$, $\mathrm{CH}_{2} \mathrm{CO}_{2} \mathrm{Me}$ ); $3.5-1.0$ (br. s, $\left.40 \mathrm{H}, \mathrm{B} 10 \mathrm{H}_{10}\right)$. UV-vis $\left(\mathrm{CH}_{2} \mathrm{Cl}_{2}\right) l_{\max } \mathrm{nm}: 438,555$, 594. MS FAB for $\mathrm{C}_{80} \mathrm{H}_{108 \mathrm{~N}} 4 \mathrm{O}_{20} \mathrm{BB}_{40 \mathrm{Ni}}(\mathrm{m} / \mathrm{e}) 1935(\mathrm{M}-1)$.

For the mouse studies, $20 \mathrm{mg}$ of porphyrin was stirred in Cremophor EL $(0.40 \mathrm{~mL})$. Propylene glycol $(0.80 \mathrm{~mL})$ was added and allowed to stir in a warm water bath. Saline $(10.8 \mathrm{~mL})$ was added dropwise with vigorous stirring. 6 


\subsection{Toxicology.}

Female 10-week-old BALB/c mice were purchased from Taconic Farm, Germantown, NY. Porphyrin in solvent or solvent alone was given to a mouse ip in three injections over a period of 8 hours $(0.060 \mathrm{~mL} / \mathrm{gbw}$ total volume given of a $1.67 \mathrm{mg} / \mathrm{mL}$ solution). Right ventricular blood was collected from lethally anesthetized (Halothane) mice for analyses 1 and boron determinations 16 hours and 4 days postinjection. Liver and proximal small intestine were removed for boron analysis.

Glucose (GLU), blood urea nitrogen (BUN), blood creatinine (BCR), alanine transaminase (ALT), aspartate transaminase (AST), alkaline phosphatase (ALP), total protein (TPR), and creatinine phosphokinase (CPK) were determined as described. 1

2.3 Boron analyses.

Direct current plasma-atomic emission spectroscopy was used (detection limit: $0.1 \mu \mathrm{g} / \mathrm{mL}$ ). Samples $(50-130 \mathrm{mg})$ were digested at $60^{\circ} \mathrm{C}$ with sulfuric acid:nitric acid (1:1). Triton X100 and water were added to give final concentrations of $15 \%$ acid and 5\% Triton X-100.

2.4 Histopathology

Microscopic sections of snap-frozen liver specimens were either stained with hematoxylin and eosin or examined unfixed, unstained and dried, for fluoresence. The three experimental groups were labeled only by code for the histopathologist (G. C. F.).

\section{RESULTS AND DISCUSSION}

Because the periphery of the porphyrin ring is so sterically hindered, its conformation is nonplanar. This reduces the aromaticity of the macrocycle and results in greater basicity of the nitrogens as demonstrated by their protonation at neutral pH, so that only the dication (all four nitrogens protonated) is observed. NMR also confirms nonplanarity of the porphyrin by the diminished ring current effect indicated by the upfield shifts of the protons closest to the pyrrole carbons. The absorption spectrum is red-shifted substantially, again indicative of the nonplanar conformation. A series of porphyrins with eight pyrrolic acetate groups and four meso phenyl groups have been reported. Their physicochemical properties are typified by those of NiTCP. ${ }^{7}$ Attempts to hydrolyze the methyl esters and/or degrade the carborane cages in order to yield a water-soluble compound led to mixtures with no major product. .

Clinical chemistry data showed no differences between any of the groups except in AST after 4 days postinjection in the VCDP group. In contrast, when a slightly higher dose of.VCDP (130 $\mu \mathrm{g} / \mathrm{gbw}$ ) in phosphate buffer was given to mice in 6 ip injections over 2 days the AST was normal (data not shown).

The stained sections of liver showed no histopathological abnormalities except for one specimen in the NiTCP group which demonstrated a minimal change, one small focus of liver cell necrosis with acute inflammatory infiltration. There were two types of fluorescence in the three groups; rapidly fading and slowly fading. The slowly fading fluorescence was present extracellularly in all three groups and is probably due to heme. The rapidly fading fluorescence was present intracellularly in only the VCDP and NiTCP groups. The intracellular uptake would account for the long retention time of the boron in the liver and most likely in the small intestine.

Figure 3. Boron concentrations of each mouse given VCDP or NiTCP $(100 \mu \mathrm{g} / \mathrm{gbw}$ in 3 ip injections) designated as V1-V5 or N1-N5, respectively, at 16 hours and 4 days postinjection, in blood, a; liver, b; and spleen, c.

Drug delivery systems similar to Cremophor, such as Tween 80, dimethylsulfoxide, liposomes and low-density lipoprotein, have been used to emulsify hydrophobic porphyrins with saline for injections that yielded tumor porphyrin concentrations up to one-third those in liver. 8

In tumor-bearing mice, injection of emulsified hydrophobic porphyrins typically yield concentrations in tumor $\approx 50 \%$ greater than in small intestine. 9 Accordingly the small intestine was used as a tumor surrogate in this pilot study. A report investigating the biodistribution of a related hydrophobic compound (phthalocyanine) injected as an emulsion, the tumor:liver ratios were 0.16 after 1 day and 0.10 after 4 days. However, tumor.intestine ratios stayed at 1.7-1.6.9 Since the similarly emulsified NiTCP injected into mice yielded $\approx 17 \mu \mathrm{g} \mathrm{B} / \mathrm{g}$ in the small intestine, it is 
expected that tumors would have yielded $\approx 26 \mu \mathrm{g} \mathrm{B} / \mathrm{g}$. Thus, we surmise that, with similar mass quantities of NiTCP and VCDP injected, boron concentrations from the former would be $\approx 4$ times more than those from the latter with minimal toxicity. 4. REFERENCES

1. M. Miura, P.L Micca, J.C. Heinrichs, D. Gabel, R.G. Fairchild, and D.N. Slatkin, Biodistribution and toxicity of 2,4-divinyl-nido-o-c arboranyldeuteroporphyrin IX in mice, Biochem. Pharm. 43:467-476, 1992.

2. M. Miura, D. Gabel, G. Oenbrink, R. Fairchild, Synthesis of boronated porphyrins for boron neutron capture therapy, Tetrahedron Lett. 31 : 2247-2250, 1990.

3. A.R. Morgan, G.M. Garbo, M. Kreimer-Bimbaum, R.W. Keck, K Chardhuri, and S.H. Selman, Morphological study of the combined effect of purpurin derivatives and light on transplantable rat bladder tumors, Cancer Res. 47: 496-498, 1987.

4. J.S. Lindsey, I.C. Schreiman, H. Hsu, P.C. Kearney, A.M. Marguerettaz, Rothemund and Adler-Longo reactions revisited: Synthesis of tetraphenylporphyrins under equilibrium conditions, J. Org. Chem. 52: 827-836, 1987.

5. G.P. Chiusoli, M. Costa, S. Reverberi, Synthesis of pyrrole-3,4-diacetic acid and its derivatives, Syn. 1989: 262-265.

6. K. Woodburn, C.K. Chang, S. Lee, B. Henderson, and D. Kessel, Biodistribution and PDT efficacy of a ketochlorin photosensitizer as a function of the delivery vehicle, Photochem.

Photobiol. 60: 154-159, 1994.

7. M. Miura, S.A. Majumder, J.D. Hobbs, M.W. Renner, L.R. Furenlid and J.A. Shelnutt, Synthesis and spectroscopic characterization of octaacetic acid-tetraphenylporphyrins, Inorg. Chem., in press.

8. A.M. Richter, E. Waterfield, A.K. Jain, A.J. Canaan, B.A. Allison and J.G. Levy, Liposomal delivery of a photosensitizer, benzoporphyrin derivative monoacid ring a (BPD), to tumor tissue in a mouse tumor model, Photochem. Photobiol. 57: 1000-1006, 1993.

9. M.M. Zuk, B.D. Rihter, M.E. Kenney, M.A.J. Rodgers and M. Kreimer-Birnbaum, Pharmacokinetic and tissue distribution studies of the photosensitizer bis(di-isobutyl octadecylsiloxy)silicon 2,3-naphthalocyanine (isoBOSINC) in normal and tumor-bearing rats, Photochem: Photobial., 59: 66-72, 1994.

Acknowledgemențs ..

This research was supported in part by the U.S. Department of Energy under Contract DE-ACO2-76CH00016. 


\section{DISCLAIMER}

This report was prepared as an account of work sponsored by an agency of the United States Government. Neither the United States Government nor any agency thereof, nor any of their employees, make any warranty, express or implied, or assumes any legal liability or responsibility for the accuracy, completeness, or usefulness of any information, apparatus, product, or process disclosed, or represents that its use would not infringe privately owned rights. Reference herein to any specific commercial product, process, or service by trade name, trademark, manufacturer, or otherwise does not necessarily constitute or imply its endorsement, recommendation, or favoring by the United States Government or any agency thereof. The views and opinions of authors expressed herein do not necessarily state or reflect those of the United States Government or any agency thereof. 


\section{DISCLAIMER}

Portions of this document may be illegible in electronic image products. Images are produced from the best available original document. 